that department organises a committee, with appropriate study groups, to prepare the documents to be submitted to the international conference. The com. mittee contains representatives of all bodies, including Government departments and industrial organisations, concerned with the technical aspects of radio communication.

The next conference of the International Com. mittee will be held in Stockholm during July 12-31, and among the subjects being studied in preparation for this are: (a) separation between frequencies assigned to radio stations; (b) international coordination of investigations on propagation; (c) methods of measurement of the field-strength of signals and of noise; (d) standard frequency and time-signal broadcasts; (e) monitoring of communication services; $(f)$ distress signals.

\section{INDIAN RESEARCH FUND ASSOCIATION}

$\mathrm{T}$ HE report of the Scientific Advisory Board of the Indian Research Fund Association (New Delhi) for the year ended December 31, 1946, gives some account of the researches carried out during the year on cholera, malaria, nutrition, leprosy, plague, pharmacology, maternity and child welfare, filariasis and other subjects, and includes the reports of the advisory committees as well as a list of papers published under the auspices of the Association, and the programme of researches and miscellaneous grants recommended for the financial year 1947-48. A cholera inquiry commenced at the Central Research Institute, Kasauli, is concerned with the substance and variability of the vibrios which may affect the efficiency of the vaccine used in cholera prophylaxis. The insecticide and mosquito repellent inquiry under the director of the Malaria Institute of India, Delhi, has covered the preparation of D.D.T. emulsion concentrates and aqueous suspensions, and field trials of D.D.T. solution, emulsions and suspensions and of 'Gammexane' solutions as residual sprays, as well as of turpentine, turpentine-toluene, and turpentinerosin soap emulsions. A mammalian malaria inquiry covered studies of the experimental mosquito transmission of Plasmodium cynomolgi to Macaca muletta monkeys and the course of the infection and of the transmission of $P$. cynomolg $i$ by blood and tissue sub-inoculation during the incubation period following sporozoite injection. An investigation of adult Anopheles stephensi was initiated at the School of Tropical Medicine, Calcutta, and another on the control of sand-flies, Phlebotomus argentipes, by spraying with D.D.T.

Nutrition researches under Dr. V. N. Patwardham at Coonoor have included studies of the vitamins of the B complex and the supplementary value of groundnut and coconut oil cakes in poor rice diets. Under Dr. B. N. Ghosh, at the University College of Science and Technology, Calcutta, studies of the biosynthesis of ascorbic acid by the rat have continued, as well as the inquiry into the chemical nature and nutritional availability of iron in foods ; and the formation, function and variations of plasma proteins in health and disease have been investigated at the Grant Medical College, Bombay. The nutrition research unit at the University of Dacca has studied the metabolism of fat, the vitamin $B$ complex, the relation between carbohydrate metabolism and nicotinic acid, the effect of soy-bean milk on growth; the similar unit at Seth G.S. Medical College, Bombay, in addition to fat metabolism, vitamin $D$ and the enzymic liberation of nicotinic acid, has studied the nutritive value of pure-bred strains of cereals and pulses. In the laboratories of the Council of Scientific and Industrial Research at Delhi, a more exact determination has been made of the vitamin $A$ activity of eighty-seven foodstuffs on the basis of individual carotenoids present. At the Women's Christian College, Madras, poor rice diets and food preparations in common use in South India have been investigated, and the evaluation of proteins in terms of hæmopoietic activity and the relation of dietary protein to blood and muscle hæmoglobin has been studied at the Biochemical Laboratory, University of Madras. The preparation of anti-rachitic substances and the nutritive value of soy-bean milk have also been studied at Poona and at Bangalore, respectively.

Leprosy research during the year at the School of Tropical Medicine, Calcutta, has included studies of promin, diasone, hydnocarpic derivatives of sulphonamides and aspergillin for the treatment of leprosy; work with stilbamidine has been continued and work with streptomycin has been concerned with its production from Actinomyces griseus. Some clinical, bacteriological and immunological work is also reported. Plague researches at the Haffkine Institute have included the effect of D.D.T. dust on the breeding of the Indian rat.fleas, Xenopsylla cheopis and $X$. astia ; fumigation work with 'Cyanogas' and experiments with D.D.T. as pulicide are also described. Among the chemical researches reported may be mentioned that on Naga sore at the Pasteur Institute, Shillong, on hypoproteinæmia and other conditions associated wrth malnutrition and on erythroblastosis fotalis and its association with the $R h$ factor at the School of Tropical Medicine, Calcutta, and the study of the anatomy of the foot with reference to infections of the foot at Stanley Hospital, Madras.

In pharmacology, the indigenous drugs inquiry has included studies of the effect of different methods of drying and of the age of the plants on the pyrethrum content of pyrethrum flower-heads, and on essential oil-bearing plants of the Kashmir valley. In the filariasis inquiry at the School of Tropical Medicine, Calcutta, the study of the action of the antimony compounds stibatin and anthiomaline was continued, while the hæmatological unit studied the blood picture and protein content of healthy Indian vegetarians. Chemotherapeutic investigations on kala-azar, the production of penicillin, anthelmintic trials of indigenous drugs against hookworm and ascaris infestation, the serological diagnosis of typhus fever by the Weil-Felix reaction and isolation of rickettsial strains, anaerobic wound infections, the manufacture of influenza virus A vaccine, the behaviour of mem. brane vaccine lymph in the field and the effect of cobra venom on the aerobic oxidation of $d$-glutamic acid are among the miscellaneous researches reported.

The reports of the advisory committees cover much the same ground but include a number of important appendixes. Among these may be mentioned a summary of work done on cholera at the Haffkine Institute, a note of the recommendations for the fortification of staple foodstuffs from the Food Fortification Sub-Committee of the Nutrition Advisory Sub-Committee, and a note on the nutritive value of 'Vanaspati' or hydrogenated vegetable oils. A 
scheme for the investigation of lathyrism, and notes on suggested lines of work on shock, the segregation and treatment of cases of tetanus with the view of clinical trials of $V-187$ in India, on the classification of clinical tetanus, and on a technique for removal of the brain and spinal cord in cases of lathyrism are also given. There are also reports on the distribution of typhus fever in the army in India, 1943-46, and of the sub-committee appointed to examine the possibility of maintaining sickness absenteeism records in Indian industries.

\section{LATIN AMERICAN CULTURES}

$\mathrm{T}$ HE Institute of Social Anthropology, which has recently been formed within the Smithsonian Institution, has started to issue an important series of monographs*. The five which have so far appeared deal with Latin America and have a very wide range. Their object is both scientific and practical, and the co-operation afforded by the national authorities both in Mexico and in Peru is a measure of the importance which they ascribe to the work. Leaving aside No. 1, on houses and house use of the Sierra Tarascans, which was published so long ago as 1944, the following brief comments are intended to give some indication of the nature of the series.

Nos. 2 and 3 are detailed studies of a small highland town in Mexico and of a coastal town of the same order of magnitude on the coast of Peru. Although the people of Cherán are Tarascan Indians, with little white blood, speaking their native language and living principally by agriculture like their forefathers, the conclusion is reached that most traits of their culture are derived from Europe. This is not to say that it is a European culture, since the contact with indigenous Tarascan elements has caused it to develop into something distinct from either ; in fact, into what Mr. Gillin, in his monograph on Moche, would describe as a Creole culture.

Moche is by comparison a drab place, as the useful series of photographs in each publication will show, but Mr. Gillin's analysis proves that its culture contains a far higher proportion of indigenous elements. The town lies almost under the shadow of the two great pyramids of Moche, and, like them, owes its name to the ancient Mochica culture; but this had at least two successors before the Spanish Conquest, so it must not be expected that much of it has survived unmodified to the present time, as Mr. Gillin is careful to point out ; and the remaining aboriginal elements are common to a number of pre-Colombian cultures rather than specific to the Mochica. The difference between the two towns is well illustrated by the accounts given of witchcraft in each of them. The data for Cheran are far from complete, but what there are have a completely European aspect, whereas those for Moche, which are fuller, have a predominantly shamanistic complexion. In spite of the aboriginal survivals, however, the author shows that Moche has a Creole culture rather than an Indian one, but considers it likely that it has changed considerably in this sense during the past generation.

- 2. Cherán: A Sierra Tarascan Village. By Ralph L. Beals. Pp. $x+225+8$ plates. 3. Moche : a Peruvian Coastal Community By John Gillin. Pp. vii $+166+26$ plates. 4. Cultural and Historical Geography of Southwest Guatemala. By Felix Webster McBryde. Pp. xv+184+47 plates. 5. Highland Communities of Central Peru a Regional Survey. By Harry Tschopik, Jr. Pp. vili $+56+15$ plates 50 cents each. (Pub. 2-5 of the Institute
No. 5 is a preliminary study, undertaken in order to choose a suitable place for more detailed work. It brings out the great variety in degree of change from Indian to white culture which is found in the Central Andes of Peru. One of its most illuminating features is a discussion of what constitutes an Indian, showing that racial criteria are so difficult to apply that a cultural definition is generally the only practicable one. In addition to introductory matter, which includes general accounts of the geography and the population, the paper contains interesting brief descriptions of most of the places visited. The town of Sicaya was chosen for further study, on the ground that it demonstrated best the process by which an Indian acquires a Mestizo culture and the Mestizo a white culture.

No. 4 is a voluminous and well-illustrated work, containing the geographical materials which an anthropologist needs to build on, particularly with regard to the use of land, and which he too often has to neglect owing to lack of specialized training. It will, presumably, be followed up by more purely anthropological studies. G. H. S. BUSHNELI

\section{FORTHCOMING EVENTS}

(Meetings marked with an asterisk * are open to the public)

\section{Saturday, May I}

British Psyohological Society (in the Physiology Theatre, University College, Gower Street, London, W.C.1), at 2.30 p.m. Mr. David Katz: "Gestalt Laws of the Body Scheme".

\section{Monday, May 3} FARMERS' CLUB (at the Royal Empire Society, Craven Street,
Strand London, w. Strand, L

LONDON SCHOOL OF ECONOMICS AND POLITICAL Sclence (at Houghton Street, Aldwych, London, W.C.2), at 5 p.m.-Prof. Fran H. Knight: "Economic Theory and the Good Society". (Furcher Lectures on May 10, 24, 31, June 7 and 14.)*

SOCIETY of ENGINERRS (at the Geological Society, Burlington House Piccadilly, London, W.1) at $5.30 \mathrm{~m}$ m.-Mr. W. T. Winter "The Development of the Jet Propulsion Engine".

ChEMICAL SocteTY, LEEDS SEcTion (in the Chemistry Department, The University, Leeds), at 6.30 p.m.- Prof. Linus C. Pauling, For Mem.R.S.: "The Valence of Metals and the Structure of Intermetallic compounds".

SOCIETY OF CHeMTCAL INDUSTRY (at the Chemical Society, Burlington House, Piccadilly, London, W.1), at 6.30 p.m.-Annual General Meeting: Mr. B. A. Southgate: "The Treatment and Disposal of Waste Waters from Industry".

Monday, May 3-Friday, May 7

LIBRARY AsSOCIATTON (in the Spa Grand Hall, Scarborough).Annual Conference.

\section{Tuesday, May 4}

COENCll For the PRESERVATION OF RURAL Enguand (at the Royal Institution of Chartered Surveyors, 12 Great George Street, London, S.W.1), at 2.30 p.m.-Annual General Meeting.

BRITISH SOCIETY FOR THE HISTORY OF SCIENCE (at the Science Museum, Exhibition Road, London, S.W.7), at 5 p.m.-Annual General Meeting.

Royal ANTHROPOLOGICAL INSTITUTE (joint meeting with the INTERNATIONAR AFRICAN INSTTTUTE, at 21 Bedford Square, London, W.C.1), at 5 p.m.-Dr. Max Gluckman, Mr. J. H. Barnes and Mr. J. C. Mitchell: "The Village Headman in British Central Africa".

Society of Chemical Industry, Chemical EngInRERING Grodp (at the Geological Societv. Burlington House, Piccadilly, London W.1), at 5.30 p.m.-Dr. J. N. Pring:"Modern Propellants Employed in British Ordnance".

\section{Wednesday, May 5}

ROYAI SOcremY OF ARTS (at John Adam Street, Adelphi, Iondon, W.C.2), at 2.30 p.m.Dr. F. G. Mann, F.R.S. : "Recent Advances in Stereochemistry" (Pope Memorial Lecture).

PHYSIOAL SOCIFTY (at the Royal Institution, 21 Albemarle Street, London, W.1), at 4 p.m.-Annual General Meeting : at 5 p.m.-Prof. Yves Rocard: "Sur les conditions d"autooscillation des systèmes vibrants" (Third Holweck Discourse).

MaNchester Literary aNd Philosophical Soctety, Soctal PhILOSOPHY SEOTION (at the Portico Library, Manchester), at 5.30 p.m.-Prof. J. A. Hawgood: "Education in Germany"."

SOCTRTY OF PUBUIC ANALYSTS AND OTHER ANALYTICAT CHEMTSTS (at the Chemical Society, Burlington House, Piccadilly, London, W.1), at 7 p.m.-Scientific Papers. 